\title{
ВЛИЯНИЕ МУЗЫКИ НА ЭКЗИСТЕНЦИАЛЬНЫЙ ОПЫТ ИНДИВИДА
}

\section{THE INFLUENCE OF MUSIC ON THE EXISTENTIAL EXPERIENCE OF THE INDIVIDUAL}

\section{E. Fetisova}

Summary: This article presents a philosophical analysis of music as a subjective art capable of making the subtle emotional states of an individual person sound. Art is born from purely intimate, existential experiences that can resonate with the inner world of the Other. This is the phenomenon of music as an art for all time. Music is in many ways capable of "speaking" with an individual being the same language, bringing to the surface those existential problems that are of concern to the individual here and now. Thus, through music, it is possible to put a part of one's existence in front of oneself, to objectify it, to make it more understandable. Music is able to resonate with the «l», it is a kind of existential dialogue that has a therapeutic effect. It is this effect that is most valuable for a person and so totally attracts music to all spheres of human life.

Keywords: existence, philosophy of music, existential experience, universal language, cultural codes, value norms.
Фетисова Евгения Николаевна

К.ф.н, доцент, ФГБОУ ВО «Тихоокеанский государственный университет», г. Хабаровск evseneya@mail.ru

Аннотация: В настоящей статье представлен философский анализ музыки как субъективного искусства, способного заставить звучать тонкие эмоциональные состояния отдельного человека. Из сугубо интимных, экзистенциальных переживаний рождается искусство, способное резонировать с внутренним миром Другого. В этом феномен музыки как искусства на все времена. Музыка способна «говорить» с индивидуальным бытием на одном языке, вытягивая на поверхность экзистенциальные проблемы, которые здесь и сейчас волнуют индивида. Таким образом, через музыку возможно поставить частичку своей экзистенции перед собой, объективировать ее, сделать более понятной. Музыка способна резонировать с «Я», это своеобразный экзистенциальный диалог, который несет терапевтический эффект. Именно этот эффект является наиболее ценным для человека и так тотально привлекает музыку во все сферы человеческого бытия.

Ключевые слова: экзистенция, философия музыки, экзистенциальный опыт, универсальный язык, коды культуры, ценностные нормы.

заставить звучать тонкие эмоциональные состояния отдельного человека. Из сугубо интимных, экзистенциальных переживаний рождается искусство, способное резонировать с внутренним миром Другого. В этом феномен музыки как искусства на все времена.

Можно сказать, что музыка является универсальным языком, поскольку он понятен всем без перевода. Не обязательно, чтобы универсальный язык состоял из слов. Его основой может служить число или нота. Великий античный философ и математик Пифагор в свое время размышлял о гармонии чисел и Природы. Одним из первых Пифагор отошел от традиции связывать природные явления с волей многочисленных мифологических богов. Мыслитель видел четкую закономерность мира, и что эту закономерность возможно объяснить языком математики. В основу мироздания философ поставил число и не ошибся. Не ошибся в том смысле, что Природу можно объяснять с помощью математических формул. Это с успехом демонстрируют современные фундаментальные науки.

Пифагор с помощью чисел исследовал гармонию музыки и сделал открытие, что музыка подчиняется простым числовым отношениям. Каким образом мыслитель
В настоящей статье представлен философский анализ музыки как субъективного искусства, способного 
пришел к этому гениальному открытию доподлинно не известно. К примеру, существует рассказ ученого IV века Ямвлиха, который утверждает, что Пифагора натолкнула на эту мысль работа кузнецов, вернее услышанная им гармония звуков от ударов молотков о железо. Современные же историки склоняются к версии Гаудецея, который в своей работе «Введение в грамматику» пишет, что Пифагор экспериментировал инструментом монохорд. Он зажимал струну монохорда в разных точках и получал различные тона, пока не фиксировал точки, где тон получался наиболее гармоничным. В результате философ впервые провел научный эксперимент и привел математические доказательства своим выводам. Так впервые человечество узнало кварты, квинты, октавы. Все эти гармоничные интервалы есть числовые пропорции. Музыкальное произведение по Пифагору, есть звучание гармонично оформленных чисел. Философ осознавал влияние музыки не только на чувства и эмоции, но и на тело и ум. Это воздействие он красиво именовал «музыкальная медицина». Пифагор считал, что музыка способна менять плохие нравы и образ жизни, совершенствовать душу. Именно с легкой руки Пифагора музыка приобретает статус философской науки, стоящей в одном ряду с астрономией, арифметикой, геометрией.

Аристотель так же считал музыку необходимым условием внутренней гармонии человека. Однако он, в противовес своему учителю Платону, не считал музыку философской наукой. Хотя и не отрицал, что музыка необходима не только для отдыха, развлечения души, но и для развития ума. Главная же ценность музыки - это ее способность изменять душу и нрав, поскольку она объединяет в себе удовольствие и красоту, помогает обрести счастье, в ней находятся «зародыши» нравственных состояний. Ученик Аристотеля Аристоксен написал множество произведений о музыке, где продолжал именовать ее наукой. Со слов А.Ф. Лосева, Аристоксена по праву можно назвать теоретиком музыки и основоположником философии музыки. Секс Эмпирик, Плутарх, Теон Смирнский и другие философы начала нашей эры считали, что именно музыка открывает путь к философии. Латинский писатель и логик Марциан Капелла включал музыку в число семи свободных искусств - спасительниц человеческой души. Немецкий натурфилософ XVIII века Новалис под музыкой понимал «уравнение мира в целом».

Гегель мыслил музыку субъективным искусством. Он был уверен, что одухотворенность музыки способствует воспроизводству всего самого сокровенного в душе человека, заставляет его чувствовать. Музыка - это душа, звучащая для себя, что дает ей полное удовлетворение. Как отдельное метафизическое понятие, включенное в онтологическую картину мира, впервые выделяет музыку Шопенгауэр. Философ считает, что сущность мироздания возможно постичь через сущность музыки. Ме- тафизическая воля по Шопенгауэру способна оставлять слепок в виде музыки.

Австрийский профессор теории, истории и эстетики музыки Эдуард Ганслик в своих трудах вводит метафизическое понятие Духа, который обладает силой оформлять. Дух он разделяет на потенциальный (звуки) и актуальный (композиторская идея). Их взаимодействие порождает музыкальную красоту - духовную форму (смысл музыки). Музыка - это особая духовная форма, противостоящая другим видам искусства. Ганслик вводит в понятийный аппарат философии музыки такое понятие как «эстетика чувства числа» [4].

Карл Дальхауз, представитель западной школы философии музыки XX века развивает идею «абсолютной музыки», разрабатывает аналитические критерии, с помощью которых важно дать эстетическую оценку музыки. Причем Дальхауз к анализу музыки применяет не только теоретический и эстетический подходы, но и исторический [8].

Еще одному видному представителю западной школы философии музыки Теодору Адорно принадлежит высказывание, ставшее устойчивым выражением: «Не мы слушаем музыку, а музыка слушает нас». Философ понимает под музыкой особую сферу искусства, где наиболее сильно проявляется свобода индивидуального творчества [1].

Выдающийся советский ученый А.Ф. Лосев в своем творчестве уделял философии музыки особое значение. Исследуя сущность музыки, Лосев очень необычно и лаконично определил ее как «жизнь числа во времени». Согласно философским взглядам ученого, музыка, как и число, автономно от любых психофизиологических и физических явлений [5]. Советского музыковеда и социолога Б.В. Астафьева интересовала тема циркуляции социальных кодов в музыке. Ученый пришел к выводу, что музыкальная форма детерминирована [3].

Все исследователи музыки сходятся во мнении, что последняя влияет на качество жизни человека. Она может как наполнить его существование позитивным смыслом, так и сподвигнуть на необдуманные поступки, меняющие личностные позиции и установки в сторону разрушения. Но личностные позиции человека по отношению к основным экзистенциальным вопросам существования тотально сказываются на качестве жизни. Человек с самого рождения помимо эмпирического опыта получает и опыт экзистенциальный, формирование которого уникально. Все мы проходим свой неповторимый путь, высвечивая ответы на вопросы о смысле жизни, смерти, свободе, ответственности. Список подобных вопросов объемен. Каждая культура на определенном отрезке времени предлагает определенный набор 
ценностных ориентиров, готовых знаний и ответов на мировоззренческие вопросы. Однако уникальность отдельного человека не позволяет умещать все в рамки общих правил и норм.

На этом фоне есть нечто постоянное, незыблемое, любимое, привычное, что помогает и поддерживает во все времена даже в таких состояниях, которые мы называем пограничными. Это искусство, которое способно преодолевать языковой барьер, сбрасывать коды культуры. Современному человеку с высоты XXI века могут быть не понятны определенные древние обряды и верования, но музыка, скульптура, живопись, архитектура вне времени и пространства.

Музыка является особым видом искусства звуков. Данное определение является ограниченным. Анализ многочисленных высказываний о музыке философов, музыкантов, ученых, обычных людей, делает это определение невероятно красивым и обширным. Подведя эти высказывания под общий знаменатель, можно сказать, что музыка - волшебство, она рисует картину мироздания, вытаскивает на поверхность коды души, является духовным языком мира материального (а это позволяет музыку осмыслять, анализировать).

Музыка - это возможность донести до Другого свою тайну, это вид общения, вид понимания. Музыка является одним из самых сильных катализаторов человеческих эмоций. Воздействуя на психику и чувства, мечты и поступки, музыка во многом формирует личность, мировоззренческие принципы и идеалы. Это искусство во все времена пронизывало бытие человека. В современное время информационных технологий музыка еще сильнее влияет на формирование нашей экзистенции, более «навязчиво» сопровождает индивидуально-личностный опыт.

Философы - экзистенциалисты впервые высветили темы, которые прежде не рассматривались, считались второстепенными. В частности, проблема экзистенциальной тревоги, которая связана с индивидуально-личностным опытом перед лицом таких данностей бытия как свобода, ответственность, любовь, одиночество, смерть, выбор и другие. Всякий человек индивидуален и интимно переживает свое становление в качестве неповторимой личности. Экзистенцию сложно свести к определенным объективациям и дать ей точное определение. Благодаря экзистенциалистам, мы принимаем, что наше человеческое бытие глубоко интимно, оно нами управляет в большей степени, чем мы им. В том смысле, что мы его не можем отменить, заменить.

Мартин Хайдеггер в свое время пришел к выводу, что бытие не подвластно ни познавательной манипуляции, ни практической. Экзистенция не может быть объективирована. К примеру, в случае с физическим экспериментом ученый обязательно задает условия его проведения и контролирует ход опыта. В случае с опытом экзистенциальным этого сделать практически невозможно. Опять же, Хайдеггер здесь говорит, что можно сделать только так, чтобы «бытие само заговорило с нами». Само бытие и является истоком экзистенциального опыта [2].

Музыка во многом способна «говорить» с индивидуальным бытием на одном языке, вытягивая на поверхность те экзистенциальные проблемы, которые здесь и сейчас волнуют индивида. Таким образом, через музыку возможно поставить частичку своей экзистенции перед собой, объективировать ее, сделать более понятной. Музыка способна резонировать с «Я», это своеобразный экзистенциальный диалог, который несет терапевтический эффект. Именно этот эффект является наиболее ценным для человека и так тотально привлекает музыку во все сферы человеческого бытия [7].

Уникальность человека формируется в сложном процессе поиска жизненных смыслов, ценностных норм. Музыка простым языком способна дать совет, поддержать в момент экзистенциальных метаний, высветить лучшее и быстрое решение. Если музыка не носит выраженный коммерческий характер, а создана на основе личных переживаний автора, если в нее вплетены авторские экзистенциальные поиски и прозрения, тогда такая музыка становится ценностью. Можно сказать, что всякое музыкальное произведение, в которое вложена частичка вселенной отдельного человека, является экзистенциальной ценностью, способной резонировать с миром Другого.

С момента рождения для человека начинается сложный путь развития его экзистенции через осуществляемые им выборы, через самоопределение, осознание себя и места своего «Я» в мире. Таким образом, индивид приходит к своей экзистенциальной идентичности. На этом пути практически в каждом моменте человека сопровождает музыка - уникальное искусство, способное отражать, обогащать, врачевать внутренний мир человека, корректировать его экзистенцию.

ЛИТЕРАТУРА

1. Адорно Теодор Избранное : Социология музыки. М.; СПб.: Университетская книга, 1998.

2. Артеменко Н.А. Фундаментальная онтология М. Хайдеггера и проблема субъективности // Гуманитарная студия. 2008. № 4. С. 9-12.

3. Астафьев Б.В. Музыка в кружках русских интеллигентов 20-40-х годов // В .б. «Музыкознание». М., 1990. 
4. анслик Эдуард 0 музыкально-прекрасном. - Опыт поверки музыкальной эстетики / Музыка: искусство, наука, мастерство. Либроком, 2021.

5. Лосев А.Ф. Основной вопрос философии музыки. Философия. Мифология. Культура. М.: Политиздат, 1991.

6. Пичко Н.С. Духовно-нравственный контент музыкально-философского пространства // Контекст и рефлексия : философия о мире и человеке. 2019. Том 8. № 5 A. C. 225-231.

7. Фетисова Е.Н. Экзистенциальная терапия рок-музыки (на примере «русского рока») / Современная наука: актуальные проблемы теории и практики. Серия: Познание. 2020. № 5. С. 105-108.

8. Чередниченко Т.В. Карл Дальхауз: философско-методологическая рефлексия истории музыки // Вопросы философии. 1999. № 9. С. 121-138.

(с) Фетисова Евгения Николаевна (evseneya@mail.ru).

Журнал «Современная наука: актуальные проблемы теории и практики»

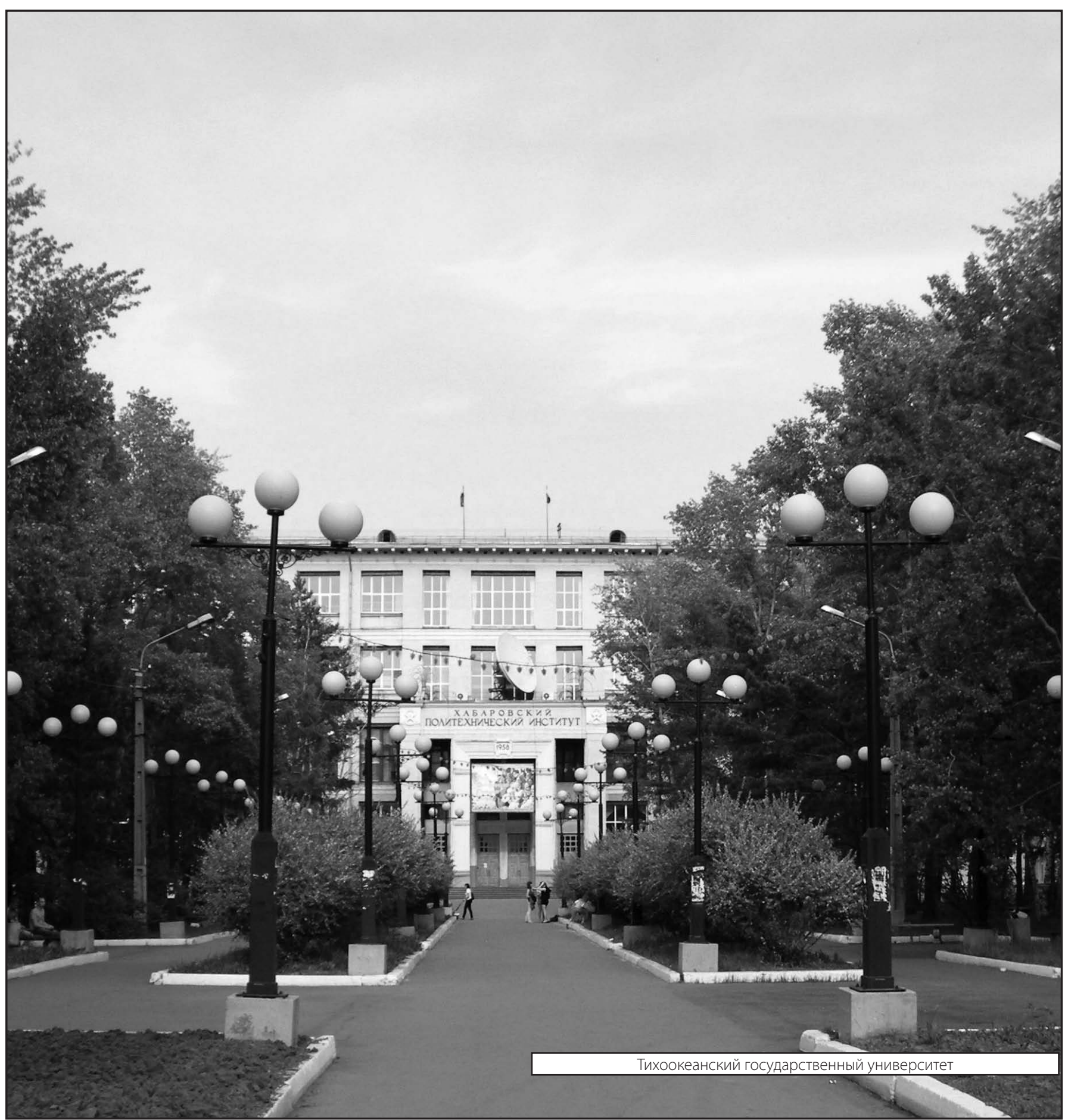

